\title{
KAJIAN DESAIN KESELAMATAN BERBASIS LOKALITAS \\ DALAM MENINGKATKAN KEPUASAN WISATAWAN \\ TERHADAP DAYA TARIK WISATA \\ (Studi Kasus Gunung Api Purba di Desa Wisata Nglanggeran)
}

\author{
Hary Hermawan \\ STP ARS Internasional Bandung \\ haryhermawan8@gmail.com
}

\begin{abstract}
Abstrack
The research is aimed to study more about the extent to which locality-based safety design can increase the satisfaction of tourists to the tourist attraction in Ancient Volcano Nglanggeran Tourism Village, Pathuk Sub-District, Gunungkidul Regency, Yogyakarta Special Region. Quantitative research methods using linear regression analysis were chosen to analyze the role of locality-based safety design allegedly to moderate the influence of tourist attraction on the satisfaction of tourists. The results showed that safety design based on locality proved unable to moderate the performance of tourist attraction in influencing the satisfaction of tourists. The recommendation of the research result is the implementation of safety with the design that has been proven effective in ensuring the safety of tourists.
\end{abstract}

Keywords : Safety design, tourist attraction, tourist satisfaction. 


\section{PENDAHULUAN}

Kunjungan wisatawan ke Daerah Istimewa Yogyakarta menunjukan kenaikan jumlah kunjungan wisata cukup besar, sejumlah 472.300 wisatawan per tahun. Akan tetapi, dari beberapa jenis destinasi yang ada, desa wisata belum mampu menarik jumlah kunjungan yang memuaskan dibanding destinasi bentuk lain (Dinas Pariwisata, 2014).

Data statistik Dinas Pariwisata tahun 2014 menunjukan walapun Kabupaten Sleman memiliki 38 desa wisata, tetapi hanya mampu menarik 218.512 kunjungan wisatawan, atau sekitar 1,30\% dari total wisatawan yang berkunjung ke destinasi wisata di Kabupaten Sleman sejumlah 16.774.235 wisatawan. Data tentang berita desa wisata yang sedang mati suri dapat kita temukan dengan mudah dengan mencari di search engine www.google.co.id dengan kata kunci "Desa wisata di Yogyakarta mati suri."

Kurangnya perhatian pengelola terhadap keselamatan wisatawan diindikasikan sebagai salah satu faktor penyebab kurangnya minat masyarakat untuk berkunjung ke desa wisata. Beberapa desa wisata yang mengandalkan daya tarik wisata alam dinilai kurang peduli terhadap aspek keselamatan dalam operasionalnya. Masih sering ditemukan pengelola desa wisata mengabaikan batas makasimal pengunjung (caring capacity), termasuk mengabaikan daya dukung lingkunganya pada saat desa wisata tersebut naik daun. Hal ini demi mengejar keuntungan yang sebesar-besarnya dari banyaknya wisatawan yang datang tanpa mau peduli terhadap aspek keselamatan.

Perlu diketahui bahwa keselamatan merupakan faktor utama yang menjadi pertimbangan wisatawan untuk memutuskan memilih destinasi wisata yang akan dikunjungi (Pizam dan Mansfeld, 1996), keselamatan juga menjadi isu strategis dalam visi pencapaian target 20 juta kunjungan wisatawan mancanegara tahun 2019 Indonesia (Teguh, 2016).

Hasil penelitian terdahulu membuktikan bahwa kebanyakan wisatawam tidak akan membelanjakan uangnya untuk pergi ke destinasi yang keselamatanya kemungkinan dalam bahaya (Pizam dan Mansfeld, 1996). Wisatawan tidak ingin berkunjung ke tempat yang menurutnya tidak aman (Adom dkk, 2012). Keselamatan bahkan disebut sebagai salah satu dari lima faktor global yang akan menekan industri pariwisata milenium baru (Chiang, 2000).

Jaminan keselamatan merupakan faktor utama yang menentukan tumbuh dan berkembangnya suatu destinasi wisata, sebagai daya tarik, dan juga termasuk nilai keunggulan yang akan menentukan kualitas sebuah destinasi wisata (Chiang, 2000). Tanpa jaminan keselamatan, destinasi wisata tidak akan mampu bersaing di pasar wisata (Adom dkk, 2012).

Jaminan keselamatan wisata telah menjadi bagian dari tuntutan masyarakat agar sebuah destinasi wisata mampu terus berkelanjutan. Perlindungan terhadap risiko dan kecelakaan berwisata, mulai dari tahap kedatangan wisatawan, kegiatan selama di destinasi wisata, sampai saat kepulangan wisatawan, merupakan tanggung jawab pengelola (Suharto, 2016).

Kabar baiknya saat ini beberapa pengelola desa wisata mulai sadar tentang pentingnya pengelolaan keselamatan wisata. Bahkan trend dalam upaya keselamatan saat ini semakin kreatif. Desain keselamatan yang dibuat oleh pengelola desa wisata cenderung tidak mengacu pedoman-pedoman kaku. Akan tetapi, aplikasi keselamatan dibuat lebih unik dan kreatif dengan desain bercorak lokalitas yang semakin kental, contohnya upaya-upaya keselamatan di destinasi wisata Gunung Api Purba Nglanggeran 
berikut: 1. Pengaplikasian informasi keselamatan dengan bahasa populer (bahasa gaul); 2. Pembuatan papan keselamatan dengan desain bercorak lokal; 3. Infrastuktur atau fasilitas keselamatan dibuat dengan bahan-bahan lokal.

Experimen Wibowo (2015) mengenai simulasi desain rambu keselamatan di destinasi wisata Pantai Parangtritis mendukung paradigma baru dalam desain rambu keselamatan. Penelitian yang dilakukanya telah membuktikan bahwa plang atau rambu peringatan dengan desain berciri budaya lokal terbukti lebih efektif dalam mentransformasikan informasi serta meningkaatkan keselamatan wisata.

Berdasarkan latar belakang diaatas peneliti tertarik untuk mengkaji lebih jauh mengenai sejauh mana desain keselamatan berbasis lokalitas mampu meningkatkan kepuasan wisatawan terhadap daya tarik wisata alam Gunung Api Purba di Desa Wisata Nglanggeran, Kecamatan Pathuk, Kabupaten Gunungkidul, D.I.Yogyakarta.

\section{Kajian Pustaka}

\section{Daya Tarik Wisata}

Menurut Undang-Undang Republik Indonesia Nomor 10 Tahun 2009, daya tarik wisata dapat dijelaskan sebagai segala sesuatu yang memiliki keunikan, keindahan, dan nilai yang berwujud keanekaragaman kekayaan alam, budaya, dan hasil buatan manusia yang menjadi sasaran atau tujuan kunjungan wisata. Secara lebih spesifik disebutkan bahwa daya tarik wisata alam, merupakan segala sesuatu yang memiliki keunikan, keindahan, keaslian, dan nilai yang berupa keanekaragaman kekayaan alam yang menjadi sasaran atau tujuan kunjungan wisatawan.

Damanik dan Weber (2006) dalam bukunya menekankan pentingnya keaslian dalam menentukan kriteria kualitas daya tarik wisata, baik dari segi originalitas, maupun otentisitasnya.

Desa Wisata Nglanggeran merupakan desa wisata yang mengandalkan daya tarik alam berupa Kawasan Ekowisata Gunung Api Purba Nglanggeran. Oleh karena itu pengembangan daya tarik wisata mengacu pada pengembangan daya tarik wisata alam seperti disebutkan diatas.

\section{Keselamatan Wisata Berbasis Lokalitas}

Pengelolaan keselamatan wisata akan selalu terkait dengan upaya-upaya meminalkan risiko dan kecelakaan.

Risiko didefinisikan sebagai sumbersumber yang mengandung unsur perusak yang potensial bagi wisatawan, operator atau destinasi, dan komunitas. Elemenelemen risiko dilihat dari siapa atau apa yang terkena dampak, atau apa yang mengalami kerugian dari setiap keadaan yang mengandung bahaya. Elemenelemen tersebut termasuk : manusia, lingkungan, fasilitas, infrastruktur, sarana umum, dan ekonomi (AICST, 2006). Risiko secara umum adalah segala sesuatu yang dapat terjadi pada diri manusia yang tidak diharapkan muncul. Semua kegiatan manusia pada dasarnya akan memiliki risiko meskipun kegiatan tersebut bertujuan untuk mencapai kesenangan saja (Yudistira \& Susanto, 2012).

Sedangkan kecelakaan didefinisikan sebagai kejadian yang tidak diinginkan, yang dapat menimbulkan cidera, kematian, kerugian, dan kerusakan pada property. Kecelakaan dapat terjadi karena kondisi simultan dari faktor manusia, faktor lingkungan, dan faktor alam sendiri (AICST, 2006).

The Workers Compensation Board (WCB) of British Columbia 2002 dalam Yudistira dan Susanto (2012) menyebutkan bahwa program keselamatan dan kesehatan adalah semua kegiatan yang meliputi pengembangan proses perencanaan manajemen resiko mencakup enam hal: 1. Perencanaan manajemen 
risiko dengan melakukan identifikasi hingga memberlakukan proses manajemen risiko; 2. Perencanaan pariwisata dengan memberlakukan prosedur yang akan menjamin keselamatan pengunjung; 3. Perencanaan respon tanggap darurat apabila munculnya kecelakaan yang terjadi di tempat wisata; 4. Aturan dan prosedur dalam menghadapi kecelakaan yang terjadi dengan mengutamakan keselamatan dan keamanan pengunjung; 5. Perencanaan media yang ada untuk meminimalisir kejadian dan memunculkan kesan yang positif; dan 6. Perencanaan setelah kejadian dengan berbagai upaya yang membutuhkan pengembalian seperti sedia kala dari tempat wisata sebelum adanya kejadian yang merugikan.

Dalam Guidelines for safe recreational water (2003) disebutkan bahwa pencegahan resiko kecelakaan dapat dilakukan dengan peningkatan keselamatan. Peningkatan keselamatan tersebut dapat diintervensi dengan 5 pendekatan yaitu : 1. Pekerjaan/ perekayasaan (engineering); 2.Memperkuat (enforment); 3. Pendidikan (education); $4 . \quad$ Tindakan untuk memberanikan (encouragement); dan 5 . Kesiapan bahaya (emergency preparadness).

Pengelola destinasi wisata yang mengandung risiko tinggi seperti wisata alam wajib memperhatikan keselamatan pengunjung dengan perencanaan dan pengendalian risiko, seperti diamanahkan dalam Undang-Undang Republik Indonesia No 10 Tahun, 2009 Pasal 26.

Desa Wisata Nglanggeran merupakan desa wisata yang mengadalkan wisata alam Kawasan Gunung Api Purba Nglanggeran serta aktifitas petualangan pendakian atau tracking sebagai daya tarik wisata utamanya. Petualangan merupakan kegiatan yang sengaja mencari risiko dan ketidakpastian hasil. Dalam wisata petualangan komersial, risiko dan ketidakpastian harus dikelola erat jika tidak dapat dihilangkan (Ewert dkk dalam Entwistle, 1923).

Cox dalam Pitana (2009) mengatakan bahwa "Pembangunan dan pengembangan pariwisata didasarkan pada kearifan lokal dan special local sense yang merefleksikan keunikan peninggalan budaya dan keunikan lingkungan." Oleh karena itu, setiap penembangan dan upaya keselamatan yang dilakukan dapat dilakukan dengan mengadopsi nilai kearifan lokal, termasuk dalam aplikasi pembuatan infrastuktur dan fasilitas keamanan.

\section{Kepuasan Wisatawan}

Kepuasan wisatawan adalah tingkat perasaan seseorang setelah membandingkan kinerja (atau hasil) yang dirasakan dibandingkan dengan harapannya (Kotler dan Makens, 1999).

Dalam bukunya yang lain, Kotler (2002) mendefinisikan kepuasan sebagai perasaan senang atau kecewa seseorang yang muncul setelah membandingkan antara persepsi/ kesannya terhadap kinerja (atau hasil) suatu produk dan harapanharapannya. Kepuasan tentang daya tarik wisata dibandingkan dengan harapan wisatawan sebelum berkunjung di daya tarik wisata tersebut.

Daya tarik wisata dan keselamatan sebagai variabel penentu kepuasan dikaji dengan pendekatan control attribution theory. Control attribution theory merupakan aspek-aspek yang dalam kendali dan tanggung jawab manusia, yang sebenarnya dapat diupayakan pengelola untuk lebih baik (Hasan, 2008). Bukan terhadap faktor-faktor risiko yang tidak bisa diprediksi dan diantisipasi.

\section{Hasil Penelitian Terhadulu}

Daya tarik wisata terbukti secara empiris sebagai faktor yang dapat menentukan tingkat kepuasan wisatawan saat berwisata di sebuah destinasi (Naidoo dkk., 2011); (Adom et al., 2012); 
(Basiya \& Rozak, 2012); dan (Darsono, 2015).

Penelitian Ayob dan Masroni (2014) dengan pendekatan kualitatif, menemukan fakta bahwa jika wisatawan merasa tidak aman dan jiwanya terancam, akan tidak puas dan cenderung menumbuhkan kesan negatif terhadap destinasi wisata.

Hasil penelitian lain menemukan bahwa keselamatan merupakan faktor utama yang menjadi pertimbangan wisatawan untuk memutuskan memilih destinasi wisata yang akan dikunjungi (Pizam dan Mansfeld, 1996); (Adom et al., 2012); dan (Chiang, 2000).

\section{Kerangka Pemikiran}

Penelitian hasil penelitian terdahulu membuktikan bahwa daya tarik wisata merupakan faktor yang terbukti secara empiris mempengaruhi kepuasan wisatawan. Sedangkan keselamatan turut menjadi pertimbangan calon wisatawan dalam memilih destinasi. Penelitan terdahulu menemukan bahwa jaminan keselamatan juga turut menentukan kualitas suatu destinasi wisata.

Masih minimnya penelitian keselamatan di suatu destinasi wisata, serta logika bahwa variabel keselamatan tidak mungkin berdiri sendiri dalam menentukan kepuasan wisatwan, maka patut diduga bahwa keselamatan merupakan variabel moderating, yang mendukung kinerja daya tarik wisata dalam mempengaruhi tingkat kepuasan wisatawan. Trend desain keselamatan dengan konsep lokalitas yang sedang marak diterapkan di berbagai desa wisata turut menentukan fokus dan tema penelitian ini.

Oleh karena itu kerangka pemikiran akan digambarkan seperti pada bagan berikut :

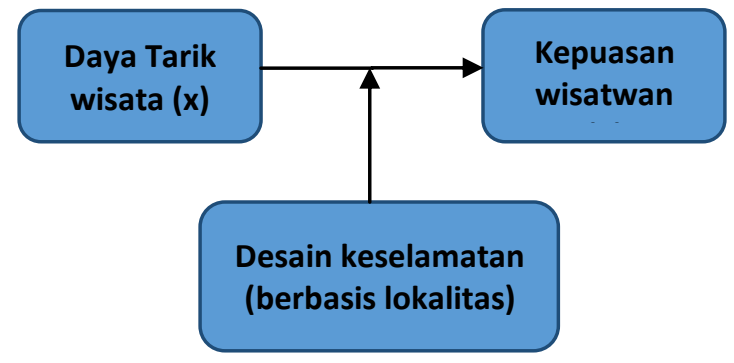

Gambar 1. Kerangka Pemikiran

\section{Hipotesis Penelitian}

Berdasarkan kajian literatur yang telah dilakukan sebelumnya, maka hipotesis alternatif penelitianya (Ha) telah dirumuskan peneliti sebagai berikut :

1. Atraksi wisata berpengaruh terhadap kepuasan wisatawan $(\mathrm{p} \neq 0)$

2. Upaya keselamatan dengan desain bercorak lokal (lokalitas) berpengaruh terhadap kepuasan wisatawan $(\mathrm{p} \neq 0)$

3. Atraksi wisata dengan moderasi keselamatan berpengaruh terhadap kepuasan wisatawan $(\mathrm{p} \neq 0)$

\section{METODE PENELITIAN}

Subjek yang menjadi sampel penelitian adalah wisatawan sejumlah 100 wisatawan yang dipilih secara acak (acidencial sampling). Sedangkan yang menjadi objek studi adalah variabel independent daya tarik wisata (x1), desain keselamatan berbasis lokalitas yang diduga sebagai variabel moderating, serta variabel dependent kepuassan (y).

Metode penelitian kuantitatif dengan menggunakan analisis regresi linear dipilih untuk menganalisis peran desain keselamatan berbasis lokalitas yang diduga memoderasi pengaruh variabel independent daya tarik wisata (x) terhadap variabel dependent kepuasan wisatawan $(\mathrm{y})$. 
Rumus regresi liner sederhana :

$\boldsymbol{y}=\boldsymbol{a}+\boldsymbol{b} \boldsymbol{x}$ (Santoso, 2016)

Rumus regresi liner dengan variabel moderator :

$y=a+b 1 \times 1+b 2 \times 2+b 3 \times 1 \times 2$ 2000)

Untuk menentukan efektifitas peranan variabel moderat dengan melihat selisih nilai $r$-square variabel independent dengan variabel mederat dibanding nilai $r$ square variabel independent tanpa variabel moderat.

Intrumen pencarian data menggunakan kuisionair dengan skala likert. Sebelum proses pencarian data dilakukan, instrumen penelitian telah diuji validitas dan reabilitas guna menjamin kesahihan data penelitian yang diperoleh. Uji validitas instrumen dilakukan dengan menggunakan analisis korelasi Pearson Product Moment. Sedangkan untuk uji realibilitas instrumen digunakan Guttman Split-Half Coefficient dengan taraf signifikansi 0,05 pada dk atau N 30 .

\section{HASIL DAN PEMBAHASAN}

\section{Profil Gunung Api Purba Nglanggeran}

Gunung Api Purba Nglanggeran merupakan kawasan ekowisata. Berupa bentang alam perbukitan yang terbentuk akibat letusan gunung api pada masa prasejarah. Gunung Api Purba Nglanggeran Terletak di Desa Nglanggeran wilayah Kecamatan Patuk, Kabupaten Gunung Kidul, Daerah Istimewa Yogyakarta. Jarak desa Nglanggeran ke ibu kota kecamatan adalah $7 \mathrm{~km}$, jarak dengan ibu kota kabupaten adalah $20 \mathrm{~km}$, sedangkan jarak dengan ibu kota provinsi sekitar $25 \mathrm{~km}$ (Hermawan, 2016a).

Gunung Api Purba Nglanggeran merupakan daya tarik wisata alam yang termasuk salah satu dari beberapa destinasi yang ada di Desa Wisata Nglanggeran. Desa Nglanggeran memiliki luas wilayah 762,7909 hektar yang secara administratif terbagi ke dalam 5 dusun yaitu Karangsari, Doga, Nglanggeran Kulon, Nglanggeran Wetan, Gunung Butak (Handoko, 2017). Seluruh pengelolaan daya tarik wisata yang ada dalam wilayah Desa Wisata Nglanggeran sejak tahun 2010 resmi dikelola oleh masyarakat lokal yang tergabung dalam Kelompok Sadar Wisata (Pokdarwis) Desa Wisata Nglanggeran (Hermawan, 2016b).

\section{Pengelolaan Daya Tarik Wisata dan Keselamatan di Gunung Api Purba Nglanggeran}

Pariwisata berbasis masyarakat atau Community Based Tourism (CBT) menjadi pedoman dalam pengelolaan pariwisata di Gunung Api Purba Nglanggeran (Hermawan, 2016b). Pegelolaan ala CBT tersebut terefleksi dalam langkah-langkah pengelolaan atraksi wisata beserta upaya keselamatan yang diterapkan.

Pengelolaan atraksi wisata dan keselamatan wisata tersebut diduga peneliti sebagai faktor utama yang menentukan kepuasan serta berdampak kepada loyalitas wisatawan. Sehingga, dari pengelolaan ketiga variabel tersebut menghasilkan performa kunjungan wisatawan di Gunung Api Purba Nglanggeran dari tahun ke tahun yang cenderung menunjukan trend positif (Hermawan, 2016a).

Daya tarik utama Kawasan Gunung Api Purba Nglanggeran adalah puncakpuncak gunung dengan pemandangan yang unik, otentik dan indah di dalam satu kawasan. Masing-masing puncak memiliki keindahan, keunikan dan nilai historis dan nilai lokalitas yang memiliki nilai luhur tersendiri, baik nilai sejarah, mitologi dan filosofi (Handoko, 2017).

Pengembangan daya tarik wisata di Gunung Api Purba Nglangeran yang ditawarkan meliputi beberapa puncak gunung berikut: Gunung kelir, Gunung 
Gede, Gunung Bongos, Gunung Blencong, dan lain sebagainya.

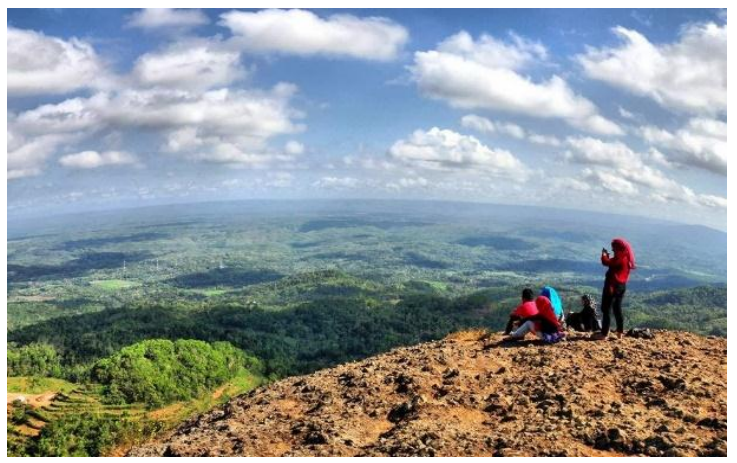

Sumber : www.gunungapipurba.com, (15 Mei 2017)

Gambar 2. Salah Satu Puncak di Gunung Api Purba Nglanggeran

Jaminan pengelolaan keselamatan yang baik telah menjadi syarat yang wajib dipenuhi sesuai ASEAN Community Based Tourism Standart tahun 2016. Oleh karena itu, pengelola Gunung Api Purba Nglanggeran telah mengupayakan keselamatan wisata berbasis lokalitas sebagai berikut :

1. Pembangunan (enginering)

Pembangunan keselamatan dengan penambahan penambahan pagar untuk pegangan pengunjung; perbaikan jalur tracking dan tangga pendakian yang berkarakter alam lokal; penambahan rambu penunjuk; rambu keamanan seperti batas aman pijakan di tebing; penanda arah jalur; penanda jalur evakuasi dan seterusnya yang semuanya dibuat dengan bahan dan desain lokal.

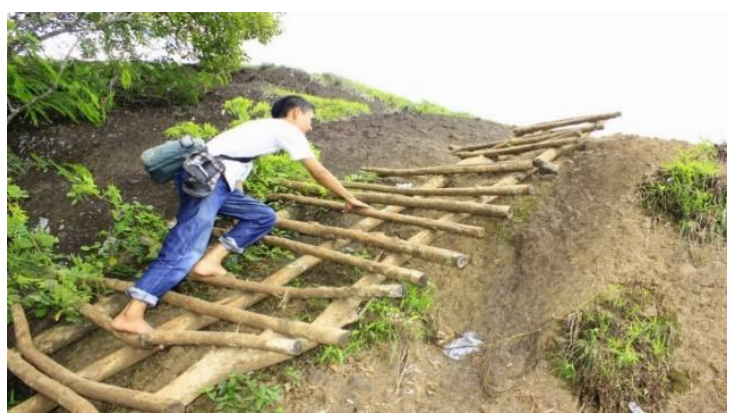

Sumber : www.gunungapipurba.com, (18 April 2017)

Gambar 3. Pembangunan Tangga Pendakian dengan Desain Lokal
2. Memperkuat (Enforment)

Upaya enforment dilakukan dengan penambahan talut di beberapa area Gunung Api Purba yang bentang alamnya miring untuk mencegah bahaya longsor. Upaya penguatan juga bertujuan untuk memperkuat kondisi lingkungan alam dan menambah daya dukung kawasan Gunung Api Purba Nglanggeran.

\section{Pendidikan (Education)}

Wisatawan cenderung merasa nyaman jika mengenal karakter lingkungan di destinasi wisata yang dikunjungi (Ross, 1998).

Simbol-simbol dan papan peringatan yang telah dibuat pengelola ditujukan untuk memberi informasi, pengenalan lingkungan juga berarti memberi pemahaman baru atau edukasi kepada wisatawan. Upaya edukasi diantaranya : penyediaan rambu petunjuk, papan informasi, peringatan, papan larangan, dan sebagainya.

Pengelola membuat rambu-rambu keselamatan berbasis lokalitas, hal ini sesuai dengan prinsip CBT yang menekankan lokalitas sebagai acuan dalam membangun segala unsur produk wisatanya

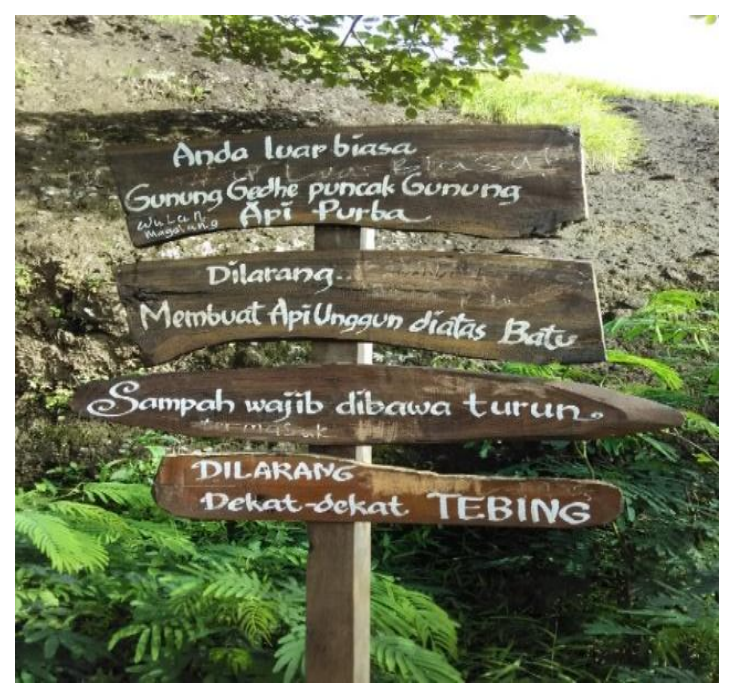

Sumber : Dokumentasi peneliti (2017)

Gambar 4. Trend Desain Papan

Keselamatan dengan Desain Lokal 
4. Tindakan untuk Memberanikan (Encouragement)

Tindakan untuk memberanikan (encouragement), dilakukan dengan upaya-upaya pemberian informasi mengenai gejala alam yang ada di Gunung Api Purba beserta cara menghadapinya, termasuk informasi dan batas-batas menganai daerah mana yang aman untuk aktifitas wisatawan dan daerah mana yang tidak aman untuk aktifitas wisatawan.

Tindakan untuk memberanikan (encouragement) dapat diimplementasikan dalam bentuk fasilitas keselamatan yang memudahkan dan membuat wisatawan merasa aman dan nyaman melakukan pendakian di Gunung Api Nglanggeran, contohnya dengan pembuatan peta sebagai orientasi atau pengenalan karakter alam sekitar.

Dalam ilmu psikologi lingkungan, wisatawan yang mengenal gambaran lingkungan yang dikunjunginya akan cenderung merasa tenteram (Ross, 1998).

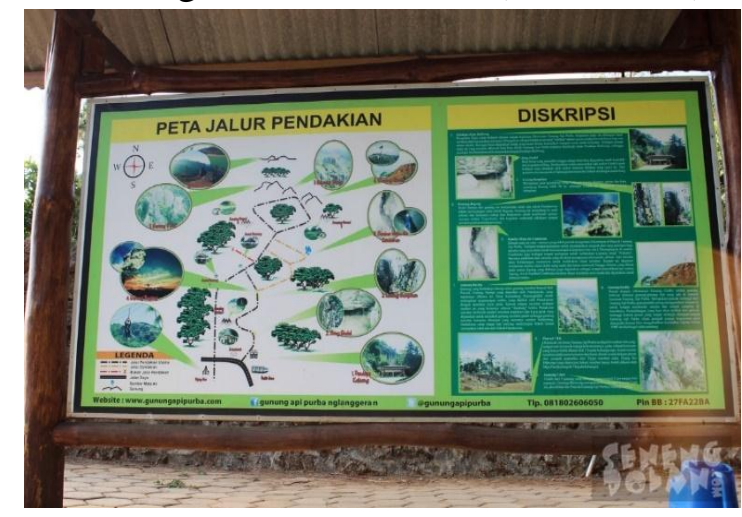

Sumber : Data Primer 2017

Gambar 5. Tindakan Encouragement dengan Peta Destinasi

Dalam standar pengelolaan CBT, informasi mengenai kondisi alam dan lingkungan yang menjadi daya tarik wisata wajib diinformasikan kepada wisatawan. Oleh karena itu media informasi wajib disediakan tuan rumah wisata (ASEAN Community Based Tourism Standart, 2016).

\section{Kesiapan Bahaya (emergency preparadness)}

Prosedur evakuasi keselamatan dan kesiapan bahaya telah dipahami oleh pengelola, sehingga pengelola selalu siap siaga jika terjadi kondisi darurat setiap saat, misalnya dengan standar prosedur dalam kecelakaan meliputi : a) Naik melawati jalur evakuasi membawa korban cidera dengan drakbar untuk di bawa ke posko; b) Memberikan pertolongan pertama oksigen dan obat-obatan yang diperlukan; c) Penanganan lebih lanjut dengan dibawa ke puskesmas jika perlu (Mursidi, wawancara 28 Desember 2016).

Kesiapan menghadapi risiko bahaya juga dilakukan dengan cara pelatihan personil dalam penanggulangan bahaya, bekerjasama dengan Badan Sars Nasional (BASARNAS) (Mursidi, wawancara 28 Desember 2016).

Tindakan kesiapan bahaya seperti diatas tidak setiap saat dapat diamati wisatawan. Oleh karena itu, kesiapan bahaya atau emergency preparadness yang digunakan sebagai indikator penelitian adalah tindakan emergency preparadness yang dapat langsung diamati (observable). Tindakan kesiapan bahaya diamati dan diukur dalam penelitian ini adalah "Ada tidaknya pengelola yang terlihat siap-sedia berjaga di destinasi wisata untuk menjamin keselamatan wisatawan."

\section{Karakteristik Data Penelitian}

Responden dalam penelitian ini adalah wisatawan Gunung Api Purba Nglanggeran yang berjumlah 100 wisatawan. Karakteristik responden digunakan untuk mengetahui gambaran umum profil responden yang menjadi subjek penelitian. Secara umum, karakteristik responden yang semakin 
bervarisi akan menghasilkan data yang juga lebih bervariasi.

Karakteristik responden dalam penelitian ini ditinjau berdasarkan beberapa aspek yang terkait dengan tipologi wisatawan (I. G. Pitana \& Putu, 2009), diantaranya : usia responden, jenis kelamin, asal wisatawan, dan motivasi berwisata di Gunung Api Purba Nglanggeran.

Karakteristik responden berdasarkan usia didominasi responden oleh wisatawan usia dewasa awal atau early adhulthood dengan presentase sebesar $76 \%$, kemudian disusul wisatawan usia paruh baya $18 \%$, dan terakhir usia remaja 6\%. Karakteristik usia early adhulthood memiliki pemikiran yang telah matang dalam berwisata, tidak tergesa-gesa atau penuh pertimbangan.

Hasil analisis karakteristik responden berdasarkan jenis kelamin, terlihat bahwa responden didominasi wanita sebesar $54 \%$, sedangkan presentase responden pria sebesar $46 \%$. Responden wanita umumnya cenderung meninjau kualitas destinasi wisata berdasarkan fasilitas yang disediakan untuk memenuhi segala kebutuhanya dibanding minat berpetualang. Hal ini didukung hasil analisis selanjutnya.

Karakteristik responden berdasarkan motivasi terlihat bahwa $51 \%$ responden yang berwisata ke Gunung Api Purba Nglanggeran memiliki motivasi untuk melepas kejenuhan dari rutinitas kerja sehari-hari. Sedangkan sisanya sebanyak $49 \%$ adalah wisatawan dengan motif petualangan.

Sedangkan karakteristik wisatawan ditinjau berdasarkan daerah asal, menunjukan mayoritas adalah wisatawan dari luar daerah sebesar $81 \%$. Kemudian, responden yang berasal dari Yogyakarta diketahui sebesar $19 \%$. Responden yang berasal dari tempat yang jauh dari daerah asalnya cenderung tidak mengenal karakteristik daya tarik wisata yang dikunjunginya, baik dalam segi lingkungan alam yang berbeda, maupun adat dan budaya baru di destinasi yang dikunjunginya. Sehingga, informasi tentang destinasi wisata sangat peting baginya (Ross, 1998).

\section{Hasil Uji Instrumen}

\section{Uji Validitas}

Variabel dayatarik wisata diukur menggunakan 5 indikator variabel meliputi keunikan, keindahan, keaslian, otentisitas dan nilai. Adapun hasil uji validitas intrumen menggunakan analisis korelasi Pearson Product Momment tersaji seperti tabel berikut :

Tabel 1. Uji Validitas Variabel Dayatarik Wisata

\begin{tabular}{llccc}
\hline Indikator & Pernyataan & R-hitung & R-tabel & Kesimpulan \\
\hline Keunikan & $\begin{array}{l}\text { Pemandangan alam disini yang tidak sama } \\
\text { dengan tempat wisata lain }\end{array}$ & 0,777 & 0,361 & Valid \\
Keindahan & $\begin{array}{l}\text { Pemandangan alam Nglanggeran sangat } \\
\text { Kembuat saya terpesona. }\end{array}$ & 0,816 & 0,361 & Valid \\
Keaslian & $\begin{array}{l}\text { Gunung Api Purba Nglanggeran benar } \\
\text { Otentisitas }\end{array}$ & 0,833 & 0,361 & Valid \\
Nilai & $\begin{array}{l}\text { Gunung Api Nglanggeran terbentuk oleh } \\
\text { fenomena alam pada masa prasejarah }\end{array}$ & 0,656 & 0,361 & Valid \\
& $\begin{array}{l}\text { Pengalaman berwisata di Nglanggeran } \\
\text { sebanding dengan waktu libur yang saya } \\
\text { korbankan untuk berkunjung. }\end{array}$ & 0,796 & 0,361 & Valid \\
\hline
\end{tabular}

Sumber : Data primer (2017) 
Uji Validitas Variabel desain pendidikan, kesiapan bahaya, penguatan. keselamatan berbasis lokalitas diukur Adapun hasil uji validitas intrumen tersaji menggunakan 5 indikator variabel seperti pada tabel berikut. meliputi : merekayasa, memberanikan,

Tabel 2. Uji Validitas Variabel Upaya Keselamatan

\begin{tabular}{llccc}
\hline Indikator & Pernyataan & R-hitung & R-tabel & Kesimpulan \\
\hline Rekayasa & $\begin{array}{l}\text { Pengelola telah membangun pagar } \\
\text { pembatas yang mecegah bahaya } \\
\text { kecelakaan wisata }\end{array}$ & 0,719 & 0,361 & Valid \\
Memberanikan & $\begin{array}{l}\text { Tersedia papan petunjuk membuat saya } \\
\text { yakin melakukan perjalanan wisata }\end{array}$ & 0,727 & 0,361 & Valid \\
Pendidikan & $\begin{array}{l}\text { Tersedia papan larangan yang membuat } \\
\text { saya mengetahui bahaya alam }\end{array}$ & 0,651 & 0,361 & Valid \\
$\begin{array}{l}\text { Kesiapan } \\
\text { Jahaya }\end{array}$ & $\begin{array}{l}\text { Ada petugas keamanan yang bersedia } \\
\text { menolong wisatawan }\end{array}$ & 0,678 & 0,361 & Valid \\
Penguatan & $\begin{array}{l}\text { Adanya bangunan yang membuat struktur } \\
\text { Gunung Api Purba Nglanggeran lebih } \\
\text { kokoh. }\end{array}$ & 0,739 & 0,361 & Valid \\
& Primer & & & \\
\hline
\end{tabular}

Sumber : Data Primer (2017)

Variabel kepuasan diukur apa yang telah diharapkan sebelum menggunakan indikator kesesuaian daya berwisata. Adapun hasil uji validitas tarik dan keselamatan yang di dirasakan intrumen tersaji seperti pada tabel berikut. konsumen di selama destinasi terhadap

Tabel 3. Uji Validitas Variabel Kepuasan Wisatawan

\begin{tabular}{llccc}
\hline Indikator & Pernyataan & R-hitung & R-tabel & Kesimpulan \\
\hline Kep. DTW 1 & $\begin{array}{l}\text { Segala yang dapat saya lihat sangat } \\
\text { indah, sesuai yang saya harapkan } \\
\text { sebelumnya }\end{array}$ & 0,855 & 0,361 & Valid \\
Kep. DTW 2 & $\begin{array}{l}\text { Alam yang saya lihat berbeda dari yang } \\
\text { lain telah sesuai harapan saya } \\
\text { sebelumnya }\end{array}$ & 0,856 & 0,361 & Valid \\
$\begin{array}{l}\text { Disini saya merasa tenteram, sesuai yang } \\
\text { Kep. }\end{array}$ & 0,803 & 0,361 & Valid \\
$\begin{array}{l}\text { Keselamatana han sebelumnya. } \\
\text { Kep. }\end{array}$ & $\begin{array}{l}\text { Disini saya merasa nyaman seperti yang } \\
\text { Keselamatan2 }\end{array}$ & 0,820 & 0,361 & Valid \\
\hline Sayarapkan sebelumnya. & & & & \\
\hline
\end{tabular}

Sumber : Data primer (2017)

Berdasarkan hasil analisis tabel 1,2 dan 3, diketahui bahwa semua item pernyataan dalam instrumen memiliki nilai r-hitung lebih besar dari nilai r-tabel sebesar 0,361 pada taraf signifikansi 0,05 dan N 30. Oleh karena itu dapat disimpulkan bahwa instrumen valid sehingga dapat digunakan untuk analisis selanjutnya.

\section{Uji Realibilitas Variabel}

Uji reliabilitas dilakukan dengan menggunakan Guttman Split-Half Coefficient. Hasil uji realibiltas seperti pada tabel 4.12, menunjukan nilai Guttman Split-Half Coefficient masingmasing variabel lebih dari nilai r-tabel pada taraf signifikansi 0,05 dan df/N 30, yaitu 0,361. Oleh karena itu dapat 
dinyatakan bahwa instrumen seluruh variabel yang diuji memiliki reliabilitas yang baik.

Tabel 4. Hasil Uji Reabilitas Instrumen

\begin{tabular}{cccc}
\hline Var & G.Koefisien & R-tabel & Kesimpulan \\
\hline X1 & 0,861 & 0,361 & Reliabel \\
X2 & 0,717 & 0,361 & Reliabel \\
Y & 0,699 & 0,361 & Reliabel \\
\hline
\end{tabular}

Sumber: Data primer (2017)

\section{Hasil Analisis Diskriptif \\ Daya Tarik Wisata Gunung Api Purba}

Hasil analisis deskriptif yang diolah berdasarikan persepsi 100 responden penelitiaan, ditemukan sebesar $36 \%$ pernyataan "sangat setuju" terhadap item pernyataan yang diajukan (sebanyak 5 item). Kemudian pernyataan "setuju" sebesar $54 \%$. Sedangkan pernyatan "netral/ tidak memihak sebesar 9\%. Terakhir hanya ditemukan sebanyak sebesar $1 \%$ pernyataan "tidak setuju".

Dari data diatas terlihat bahwa sebagian besar responden memiliki persepsi yang positif atau dapat disimpulkan bahwa Gunung Api Purba Nglanggeran memiliki daya tarik wisata alam yang berkualitas.

\section{Desain Keselamatan Wisata Berbasis Lokalitas}

Hasil analisis deskriptif berdasarkan persepsi 100 responden penelitiaan, ditemukan sebesar 9\% pernyataan "sangat setuju" terhadap keseluruhan item pernyataan yang diajukan (15 item). Kemudian juga diketahui terdapat sebesar $45 \%$ pernyataan "setuju." Pernyatan "netral/ tidak memihak," sebesar 29\%. sedangkan pernyataan negatif "tidak setuju" ditemukan sebesar $14 \%$, disusul pernyataan "sangat tidak setuju" sebesar $3 \%$.

Dari data diatas dapat disimpulkan bahwa kecenderungan pandangan responden terhadap desain dan upayaupaya keselamatan yang diterapkan di
Gunung Api Purba Nglanggeran adalah positif atau memenuhi kriteria keselamatan.

\section{Kepuasan Wisatawan di Gunung Api Purba Nglanggeran}

Berdasarkan hasil analisis diskriptif dari persepsi 100 responden menunjukan bahwa penelitiaan, sebesar $25 \%$ responden menyatakan "sangat setuju" terhadap keseluruhan item pernyataan yang diajukan. Kemudian juga diketahui terdapat 49\% pernyataan "setuju." Pernyatan "netral/ tidak memihak," diketahui terdapat sebesar $21 \%$ dari keseluruhan item pertanyaan yang diajukan. Sedangkang pernyataan negatif "tidak setuju" ditemukan sebesar 3\% dari keseluruhan item pertanyaan yang diajukan, disusul pernyataan "sangat tidak setuju" sebesar $2 \%$.

Berdasarkan kecenderungan data yang mayoritas menunjukan sikap positif seperti diatas, maka ,dapat disimpulkan bahwa secara umum tingkat kepuasan responden terhadap daya tarik wisata, keselamatan, dan sarana wisata di Gunung Api Purba Nglanggeran adalah memuaskan.

\section{Hasil Uji Normalitas Data}

Analisis regresi mensyaratkan data berdistribusi normal, untuk mengetahui normalitas data dapat dilihat menurut tabel PP-Plots hasil regresi berikut :

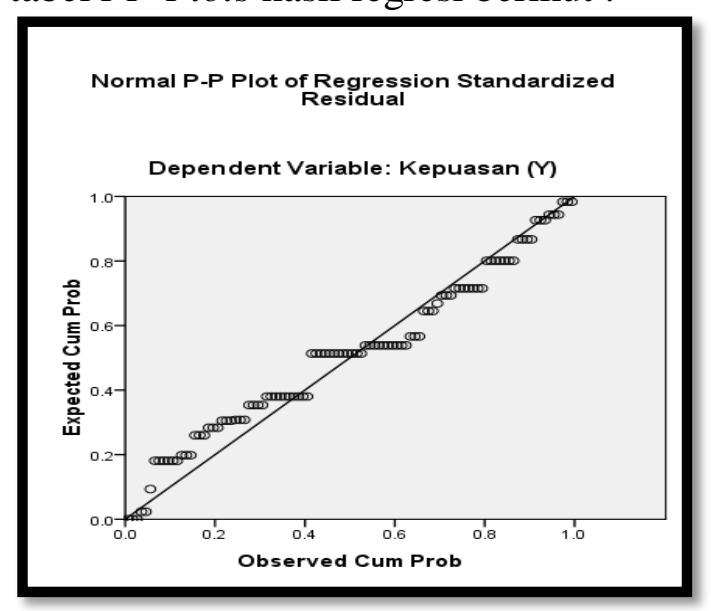

Gambar 6. P-P Plots 
Dari gambar 6 terlihat bahwa distribusi data cenderung mengikuti garis regresi, sehingga dapat disimpulkan bahwa data telah memenuhi asumsi normalitas.

\section{Pengaruh Dayatarik Wisata terhadap kepuasan Wisatawan}

Hasil uji pengaruh variabel daya tarik wisata terhadap kepuasan wisatawan terlihat pada tabel-tabel berikut :

Tabel 5. Model Sumary 1

\begin{tabular}{lrrr}
\hline & $R$ & $\begin{array}{c}\text { Adjusted } \\
R\end{array}$ & $\begin{array}{c}\text { Std. Error of the } \\
\text { Estimate }\end{array}$ \\
\hline $.584^{\mathrm{a}}$ & .340 & .334 & 2.118
\end{tabular}

a. Predictors: (Constant), Daya Tarik Wisata (X)

b. Dependent Variable: Kepuasan (Y)

Sumber : Data primer (2017)

Tabel 6. Koefisien 1

\begin{tabular}{lrrrr} 
& \multicolumn{5}{c}{ Std. } \\
& \multicolumn{1}{c}{$B$} & Error & \multicolumn{1}{c}{$t$} & Sig. \\
\hline 1 (Constant) & 4.465 & 1.728 & 2.584 & .011 \\
Daya & .717 & .101 & 7.113 & .000 \\
$\quad$ Tarik & & & & \\
$\quad$ Wisata (X) & & & &
\end{tabular}

a. Dependent Variable: Kepuasan (Y)

Sumber : Data primer (2017)

Berdasarkan analisis regresi tabel 5 (model sumary) diketahui nilai $r$-square sebesar 0,34 atau 34\%. Dengan demikian dapat disimpulkan bahwa daya tarik wisata di Desa Wisata Nglanggeran mempengaruhi kepuasan wisatawan sebesar 34\%, sedangkan $66 \%$ sisanya dipengaruhi variabel lain diluar variabel daya tarik wisata.

Berdasarkan tabel 6 atau output koefisien, menunjukan nilai konstan/ alpha sebesar 4.465 dan signifikasi 0,011 lebih kecil dari 0,05. Bermakna, tanpa variabel daya tarik wisata kepuasan wisatawan di desa wisata Nglanggeran adalah 4.465 dan terbukti signifikan. Sedangkan nilai koefisien sebesar 0,717, yang bermakna bahwa setiap upaya peningkatan daya tarik wisata sebesar 1 satuan akan mempengaruhi kepuasan sebanyak 0,717. Nilai 0,000 lebih kecil dari nilai alpa 0,05 bermakna bahwa pengaruh daya terik wisata terhadap kepuasan wisatawan terbukti dan terpercaya pada taraf kepercayaan $95 \%$. Dari tabel 6 dapat dirumuskan garis regresi sebagai berikut : $y=4,465+0,717 x$

\section{Pengaruh Keselamatan Wisata dengan Desain Lokal terhadap Kepuassan Wisatawan}

Hasil uji pengaruh keselamatan wisata dengan desain lokal terhadap kepuasan wisatawan tersaji dalam tabel berikut :

Tabel 7. Model Sumary 2

\begin{tabular}{|c|c|c|c|c|}
\hline Model & $\mathrm{R}$ & $\begin{array}{c}\mathrm{R} \\
\text { Square }\end{array}$ & $\begin{array}{l}\text { Adjusted } \\
\text { R Square }\end{array}$ & $\begin{array}{l}\text { Std. Error } \\
\text { of the } \\
\text { Estimate }\end{array}$ \\
\hline & $.191^{\mathrm{a}}$ & .036 & .027 & 2.560 \\
\hline \multicolumn{5}{|c|}{$\begin{array}{l}\text { a. Predictors: (Constant), Keselamatan } \\
\text { b. Dependent Variable: Kepuasan (Y) }\end{array}$} \\
\hline \multicolumn{5}{|c|}{ Sumber : Data primer (2017) } \\
\hline & & & oefisien 2 & \\
\hline
\end{tabular}

\begin{tabular}{lrrrr} 
Model & \multicolumn{5}{c}{ Std. } \\
\hline Constant $)$ & 14.069 & 1.369 & 10.274 & .000 \\
Kes $(\mathrm{X} 2)$ & .153 & .079 & 1.926 & .057
\end{tabular}

a. Dependent Variable: Kepuasan (Y)

Sumber : Data primer (2017)

Berdasarkan analisis regresi tabel 7 (model sumary 2) diketahui nilai $r$-square sebesar 0,036 atau 3,6\%. Akan variabel keselamatan pada tabel 8 memiliki nilai signifikansi 0,057 yang lebih besar dibanding alpha 0,05 pada taraf kepercayaan 95\%. Hal ini menunjukan bahwa desain keselamatan berbasis 
lokalitas tidak berpengaruh terhadap kepuasan wiatawan.

Pengaruh Dayatarik Wisata terhadap Kepuasan Wisatawan dengan Desain Keselamatan Berbasis Lokalitas sebagai Variabel Moderating

Hasil uji pengaruh variabel dayatarik wisata terhadap kepuasan wisatawan dengan keselamatan sebagai variabel moderating tersaji dalam tabel berikut :

Tabel 9. Model Sumary 3

\begin{tabular}{llrrr} 
Model & $\mathrm{R}$ & $\begin{array}{c}\mathrm{R} \\
\text { Square }\end{array}$ & $\begin{array}{c}\text { Adj R } \\
\text { Square }\end{array}$ & $\begin{array}{l}\text { Std. Error of } \\
\text { the Estimate }\end{array}$ \\
\hline 1 & $.587^{\mathrm{a}}$ & .345 & .324 & 2.132
\end{tabular}

a. Predictors: (Constant), Daya Tarik Wisata (X1), Keselamatan (X2), Moderasi (X1*X2)

b. Dependent Variable: Kepuasan (Y)

Sumber : Data primer (2017)

Tabel 10. Koefisien 3

\begin{tabular}{|c|c|c|c|c|c|}
\hline \multirow[b]{2}{*}{ Model } & \multicolumn{2}{|c|}{$\begin{array}{l}\text { Unstandardized } \\
\text { Coefficients }\end{array}$} & \multirow[b]{2}{*}{ Beta } & \multirow[b]{2}{*}{$\mathrm{t}$} & \multirow[b]{2}{*}{ Sig. } \\
\hline & B & $\begin{array}{l}\text { Std. } \\
\text { Error }\end{array}$ & & & \\
\hline (Constant) & 7.443 & 10.290 & & .723 & .471 \\
\hline $\begin{array}{l}\text { Daya Tarik } \\
\text { Wisata }(X 1)\end{array}$ & .500 & .582 & .407 & .859 & .393 \\
\hline $\begin{array}{l}\text { Keselamatan } \\
\text { (X2) }\end{array}$ & -.156 & .594 & -.196 & -.263 & .793 \\
\hline $\begin{array}{l}\text { Moderasi } \\
(\mathrm{X} 1 * \mathrm{X} 2)\end{array}$ & .012 & .033 & .335 & .348 & .728 \\
\hline
\end{tabular}

Sumber : Data primer (2017)

Berdasarkan analisis output pada tabel 9 (model sumary), diketahui bahwa pengaruh variabel dayatarik wisata terhadap kepuasan wisatawan dengan keselamatan berbasis lokalitas sebagai variabel moderating menunjukan nilai $r$ square 0,345 atau $34,5 \%$. Jika dibandingkan dengan nilai r-square pengaruh daya tarik wisata terhadap kepuasan tanpa variabel moderat pada tabel 6 sebesar $34 \%$ sekilas terlihat peningkatan sebesar $0,5 \%$.
Akan tetapi jika melihat analisis koefisien pada tabel 10 terlihat bahwa daya tarik wisata dengan moderasi justru tidak signifikan.

Dengan begitu dapat disimpulkan bahwa desain keselamatan berbasis lokalitas tidak berperan dalam meningkatkan kepuasan wisatawan terhadap daya tarik wisata di Gunung Api Purba Nglanggeran.

\section{SIMPULAN}

Wisatawan di Gunung Api Nglanggeran didominasi wisatawan muda dengan usia antara 21 tahun sampai 40 tahun. Wisatawan dengan rentang usia ini tergolong wisatwan dewassa awal yang telah matang dalam berfikir serta mengambil keputusan didukung kondisi fisik yang masih prima. Mayoritass wisatawan gunung api purba adalah wanita. Ditinjau dari daerah asal wisatawan, mayoritas wisatawan berasal dari luar wilayah D.I.Yogyakarta.

Berdasarkan hasil anlisis terlihat jelas bahwa daya tarik wisata di Destinasi Wisata Nglanggeran terbukti berpengaruh terhadap kepuasan wiatawan sesuai dengan teori dan hasil-hasil penelitian terdahulu (Naidoo dkk., 2011); (Adom dkk., 2012); (Basiya \& Rozak, 2012); dan (Darsono, 2015). Bahkan Gunung Api Purba Nglenggeran dengan segala keunikan, keindahan, keaslian, serta nilai yang ditawarkan mampu memikat memikat pengujung yang mayoritas berasal dari luar Daerah Istimewa Yogyakarta.

Keselamatan tidak terbukti berpengaruh terhadap kepuasan wisatawan. Hal ini dapat dimungkinkan karena sebagian responden adalah wisatawan dengan motif petualang. Yang senang mengunjungi daerah baru yang belum diketahuinya, senang mencari hal baru yang tidak umum (I. G. Pitana \& Gayatri, 2005). Motif petualang biasanya 
memiliki kecenderungan untuk lebih mementingkan kepuasan pengalaman dan cenderung suka mengambil risiko.

Desain keselamatan berbasis pada lokalitas (special local sense), terbukti tidak mampu memoderasi kinerja daya tarik wisata dalam mempengaruhi kepuasan wisatawan. Penemuan ini jelas tidak sesuai dengan saran Cox, yang menyarankan agar setiap pembangunan atau pengembangan pariwisata didasarkan pada kearifan lokal dan special local sense, merefleksikan keunikan peninggalan budaya, serta keunikan lingkungan" (Cox dalam Pitana, 2009). Hal ini juga tidak mendukung penemuan sebelumnya dari Wibowo (2015) bahwa keselamatan dengan desain dan arsitekstur bercorak lokal lebih efektif.

Implikasi manajerial dari penemuan ini adalah masukan dalam upaya keselamatan. Aplikasi desain keselamatan wisata hendaknya jangan semata-mata mempertimbangkan special local sense, atau dengan tujuan mengikuti trend semata. Karena telah terbukti keselamatan berbasis lokalitas tidak memiliki peran sama sekali dalam meningkatkan kinerja daya tarik wisata dalam mempengaruhi kepuasan wisatawan.

Desain dan upaya keselamatan yang telah teruji efektifitasnya jauh lebih baik baik untuk diterapkan, mengingat jaminan keselamatan pengunjung merupakan hal yang utama serta mutlak menjadi kewajiban pengelola destinasi wisata, walaupun banyak wisatwan petualang yang kurang memperhatikan hal-hal terkait keselamatan wisata misalnya rambu-rambu. Akan tetapi, perlu dipertimbangkan pengunjung lain yang belum memiliki pemahaman yang baik mengenai karakter alam, karena hasil penelitian menunjukan bahwa sebagian besar wisatawan adalah wisatawan dengan motif bersenang-senang (leisure). Sehingga, faktor risiko serta potensi kecelakaan perlu dikelola dengan sistem manajemen keselamatan yang baik.

Saran untuk penelitian berikutnya dalam hal kajian desain keselamatan adalah dengan melakukan uji tehnik, meninjau efektifitas desain atau upaya keselamatan dengan experiment yang terukur.

\section{DAFTAR PUSTAKA}

Adom, Y. A., Jussem, B., Pudun, J., \& Azizan, Y. (2012). Factors that Influence Visitor's Satisfaction Toward Kuching Waterfront. Journal for the Advancement of Scient \& Art, 45.

AICST, A. (2006). Plan of Action for Sustainable Tourism Management in Asia and the Pacific. Phase II(20062012).

ASEAN Community Based Tourism Standart. (2016). Jakarta: ASEAN Secretariat. Retrieved from public@asean.org

Ayob, N. M., \& Masroni, T. (2014). Issues of Safety and Security: New Challenging to Malaysia Tourism Industry. In SHS Web of Conferences (Vol. 12, pp. 1-10).

Basiya, R., \& Rozak, H. A. (2012). Kualitas Daya Tarik Wisata, Kepuasan dan Niat Kunjungan Kembali Wisatawan Mancanegara di Jawa Tengah. Jurnal Ilmiah Dinamika Kepariwisataan, 11(2).

Chiang, L. C. (2000). Strategies for safety and security in tourism: a conceptual framework for the Singapore hotel industry. Journal of Tourism Studies, 11(2), 44.

Damanik, J., \& Weber, H. F. (2006). Perencanaan Ekowisata dari Teori ke Aplikasi. diterbitkan atas kerjasama Pusat Studi Pariwisata (PUSPAR) Universitas Gadjah Mada dan Penerbit Andi. Yogyakarta. 
Darsono, R. (2015). Pengaruh Kualitas Daya Tarik Wisata terhadap Tingkat Kepuasan Wisatawan, Studi Kasus di Waduk Jatiluhur-Kabupaten Purwakarta. JURNAL NASIONAL PARIWISATA, 5(1), 14-22.

Dinas Pariwisata, D. I. Y. (2014). Statistik Kepariwisataan 2014. Yogyakarta, DIY. Retrieved April (Vol. 21). D.I. Yogyakarta Indonesia.

Entwistle, W. J. (1923). The Adventure of" Le Cerf au Pied Blanc" in Spanish and Elsewhere. The Modern Language Review, 18(4), 435-448.

Guidelines for safe recreational water. Volume 1, coastal and fresh waters. (2003). Risk Management (Vol. 1).

Handoko, S. (2017). Gunung Api Purba Nglanggeran. Retrieved April 3, 2017, from www.gunungapipurba.com

Hermawan, H. (2016a). Dampak Pengembangan Desa Wisata Nglanggeran Terhadap Ekonomi Masyarakat Lokal. Jurnal Pariwissata, III(2).

Hermawan, H. (2016b). Dampak Pengembangan Desa Wisata Nglanggeran Terhadap Sosial Budaya Masyarakat Lokal. In Seminar Nasional Ilmu Pengetahuan dan Teknologi Komputer Nusa Mandiri Pertama Tahun 2016 (Vol. 1, pp. 426-435). SNIPTEK Nusa Mandiri.

Indonesia, P. R. Undangundang No. 10 Tahun 2009 tentang Kepariwisataan, Sekretariat Negara. Jakarta § (2009).

Kotler, P. (2002). Manajemen Pemasaran, terjemahan Hendra Teguh, edisi Millenium, cetakan pertama (1st ed.).
Jakarta: Prenhalindo.

Kotler, P., \& Makens, J. C. (1999). Marketing for Hospitality and Tourism, 5/e. Pearson Education India.

Naidoo, P., Ramseook-Munhurrun, P., \& Seegoolam, P. (2011). An Assessment of Visitor Satisfaction with Nature-Based Tourism Attractions.

Pitana, I. (2009). Pengantar Ilmu Pariwisata. Yogyakarta: andi.

Pitana, I. G., \& Gayatri, P. G. (2005). Sosiologi pariwisata. Yogyakarta: Penerbit Andi.

Pitana, I. G., \& Putu, G. (2009). Sosiologi Pariwisata. Yogyakarta: Andi.

Pizam, A., \& Mansfeld, Y. (1996). Tourism, crime, and international security issues. John Wiley \& Son Ltd.

Ross, G. F. (1998). Psikologi Pariwisata. Jakarta: Yayasan Obor Indonesia.

Santoso. (2016). Statistika Hospitalitas. Yogyakarta: Deepublish.

Suharto. (2016). Dengan, Hubungannya Destinasi, Citra Kasus, Studi Loka, Gembira. Jurnal Media Wisata, 14(1), 287-304.

Umar, H. (2000). Metodologi Penelitian. Jakarta: Gramedia Pustaka Utama.

Wibowo, A. (2015). Kajian Simulasi Desain Rambu Informasi Keselamatan di Tempat Wisata Pantai Parangtritis Berdasatkan Perilaku Budaya. JURNAL ITENAS REKARUPA, 3(1), 20088-5121.

Yudistira, I. G. A. A., \& Susanto, A. (2012). Keselamatan Pengunjung Tempat Wisata. WIDYA, 29(320). 